Article

\title{
Survival, Growth, and Reproduction: Comparison of Marbled Crayfish with Four Prominent Crayfish Invaders
}

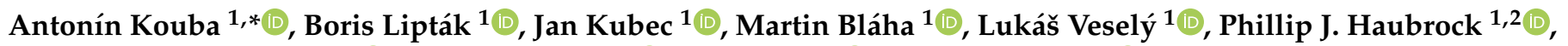 \\ Francisco J. Oficialdegui ${ }^{3}\left(\mathbb{D}\right.$, Hamid Niksirat $^{1}{ }^{(D}$, Jiří Patoka ${ }^{4}(\mathbb{D})$ and Miloš Buřič ${ }^{1}(\mathbb{D})$ \\ 1 South Bohemian Research Center of Aquaculture and Biodiversity of Hydrocenoses, Faculty of Fisheries and \\ Protection of Waters, University of South Bohemia in České Budějovice, Zátiší 728/II, \\ 38925 Vodňany, Czech Republic; liptaq.b@gmail.com (B.L.); kubecj@frov.jcu.cz (J.K.); blaha@frov.jcu.cz (M.B.); \\ veselyl@frov.jcu.cz (L.V.); phillip.haubrock@senckenberg.de (P.J.H.); niksirat@frov.jcu.cz (H.N.); \\ buric@frov.jcu.cz (M.B.) \\ 2 Department of River Ecology and Conservation, Senckenberg Research Institute and Natural History \\ Museum Frankfurt, Clamecystrasse 12, 63571 Gelnhausen, Germany \\ 3 Department of Wetland Ecology, Doñana Biological Station (EBD-CSIC), C/Américo Vespucio 26, Isla de la \\ Cartuja, 41092 Seville, Spain; oficialdegui@ebd.csic.es \\ 4 Department of Zoology and Fisheries, Faculty of Agrobiology, Food and Natural Resources, Czech University \\ of Life Sciences Prague, Kamýcká 129, 16500 Prague-Suchdol, Czech Republic; patoka@af.czu.cz \\ * Correspondence: akouba@frov.jcu.cz
}

check for

updates

Citation: Kouba, A.; Lipták, B.; Kubec, J.; Bláha, M.; Veselý, L.; Haubrock, P.J.; Oficialdegui, F.J.; Niksirat, H.; Patoka, J.; Buřič, M. Survival, Growth, and Reproduction: Comparison of Marbled Crayfish with Four Prominent Crayfish Invaders. Biology 2021, 10, 422. https:// doi.org/10.3390/biology10050422

Academic Editor: Ettore Randi

Received: 31 March 2021

Accepted: 6 May 2021

Published: 10 May 2021

Publisher's Note: MDPI stays neutra with regard to jurisdictional claims in published maps and institutional affiliations.

Copyright: (c) 2021 by the authors. Licensee MDPI, Basel, Switzerland. This article is an open access article distributed under the terms and conditions of the Creative Commons Attribution (CC BY) license (https:/ / creativecommons.org/licenses/by/ $4.0 /)$.
Simple Summary: Biological invasions exert tremendous impacts on native biodiversity and ecosystem functioning. Invasive crayfish species are well known for their particularly vigorous impacts. Recent research indicated that locations with multiple invasive crayfish species are increasing, yet questions asking which species and under what circumstances will dominate have remained unanswered. Conducting a set of independent trials of single-species stocks (intraspecific interactions) and mixed stocks (interspecific interactions) of marbled crayfish in combination with other four crayfish species invasive to Europe we evaluated survival, growth, claw injury, and reproduction. In both single and mixed stocks, red swamp crayfish and common yabby grew faster than marbled crayfish, while marbled crayfish were superior to both spiny-cheek and signal crayfish in terms of growth. Except for the trial with signal crayfish, the faster-growing species consistently reached a higher survival rate. Thus, the success of the marbled crayfish is significantly driven by its relatively fast growth as well as early and frequent reproduction. Our results indicate how interactions between invasive populations can unfold in the future and underline the complex population dynamics between existing and emerging invasive species.

Abstract: Biological invasions are increasingly recognized ecological and economic threats to biodiversity and are projected to increase in the future. Introduced freshwater crayfish in particular are protruding invaders, exerting tremendous impacts on native biodiversity and ecosystem functioning, as exemplified by the North American spiny-cheek, signal and red swamp crayfish as well as the Australian common yabby. The marbled crayfish is among the most outstanding freshwater crayfish invaders due to its parthenogenetic reproduction combined with early maturation and high fecundity. As their introduced ranges expand, their sympatric populations become more frequent. The question of which species and under what circumstances will dominate in their introduced communities is of great interest to biodiversity conservation as it can offer valuable insights for understanding and prioritization of management efforts. In order to examine which of the aforementioned species may be more successful as an invader, we conducted a set of independent trials evaluating survival, growth, claw injury, and reproduction using single-species stocks (intraspecific interactions) and mixed stocks (interspecific interactions) of marbled crayfish vs. other crayfish invaders since the onset of exogenous feeding. In both single and mixed stocks, red swamp crayfish and yabby grew faster than marbled crayfish, while marbled crayfish were superior to both spiny-cheek and signal crayfish in terms of growth. With the exception of signal crayfish, the faster-growing species consistently reached a higher survival rate. The faster-growing species tended to negatively impair smaller 
counterparts by greater claw injury, delayed maturation, and reduced fecundity. Only marbled crayfish laid eggs as early as 14 weeks in this study, which is earlier than previously reported in the literature. Thus, the success of marbled crayfish among invasive crayfish is significantly driven by relatively fast growth as well as an early and frequent reproduction. These results shed light on how interactions between invasive populations can unfold when their expansion ranges overlap in the wild, thereby contributing to the knowledge base on the complex population dynamics between existing and emerging invasive species.

Keywords: biological invasion; pet trade; animal release; species interactions; sympatry

\section{Introduction}

The accelerating rates of international trade, travel, and transport are leading to a mixing of biota across the world and the number of species introduced to new regions continues to increase worldwide [1-3]. This is true for many taxonomic groups [4-7]. Some of these introduced organisms become established and invasive in new environments, continuing to spread and negatively affecting their introduced environment $[8,9]$. The economic costs related to such biological invasions are overwhelming and remain underestimated in many cases $[10,11]$. More importantly, these invasions often result in irreversible changes of newly occupied ecosystems. Thus, they are considered as one of the major threats of biodiversity and ecosystem functioning globally [12-14].

In the face of overwhelming numbers of introduced and invasive species [15], the need to better understand interspecific interactions among invaders in recipient ecosystems has never been greater. While many of these interactions (antagonistic, mutualistic, or competitive) have been primarily described comparing invasive species and their native counterparts, interactions among invasive species have received less attention [16]. In these complex scenarios, more opportunistic life-history strategies (' $r$-selected') of invasive species can facilitate their invasion success $[17,18]$. The study of life-history traits of emerging invasive species vs. already established invasive species is, therefore, of vital importance to predict the outcome of introductions in the future.

Crayfish (Decapoda: Astacidea) are a highly diverse taxonomic group of freshwater organisms [19] with important ecological roles in freshwater ecosystems [20,21]. Numerous crayfish species have been introduced worldwide and exerted serious negative impacts on resident biodiversity. For instance, a large number of populations of indigenous crayfish species (ICS) in Europe have been lost, and many more have been substantially reduced, due to direct or indirect effects of non-indigenous crayfish species (NICS), primarily of North American origin, such as spiny-cheek crayfish Faxonius limosus (Rafinesque, 1817), signal crayfish Pacifastacus leniusculus (Dana, 1852), and red swamp crayfish Procambarus clarkii (Girard, 1852) [22,23]. These species have relatively long introduction histories on the European continent, where they are widely spread [24,25], and are listed as invasive alien species of EU concern [26,27]. North American crayfish transmit the causative agent (Aphanomyces astaci Schikora) of the crayfish plague, a deadly disease to all crayfish not originating from North America [28]. Crayfish plague transmission aside, previous studies demonstrated the superiority of NICS over European ICS [29-31], in terms of higher aggressiveness and dominance in mutual interactions, higher competitiveness for resources such as food and shelter, faster growth and maturation, shorter egg incubation, and higher fecundity accompanied with a broader environmental tolerance [23,32,33].

Over the last decades, several more NICS than the three aforementioned species have been introduced in Europe. For instance, Kouba et al. [25] listed a total of seven further successfully established NICS, such as Faxonius virilis (Hagen, 1870), F. juvenilis (Hagen, 1870), and F. immunis (Hagen, 1870), Cherax destructor Clark, 1936, C. quadricarinatus (von Martens, 1868), Procambarus acutus (Girard, 1852), and P. virginalis Lyko, 2017, with newly introduced populations appearing frequently across the continent [34,35]. As the number 
of NICS and their ranges expand, novel assemblages containing multiple NICS gradually occur [34,36,37]. However, studies simultaneously comparing life-history trait differences and possible interactions among multiple NICS are particularly limited [30,38-40]. Among newly appearing species, the parthenogenetic marbled crayfish $P$. virginalis has become particularly widespread and concerning due to its reproduction strategy when theoretically even a single individual can establish a new population [37,41].

Using single-species and mixed stocks of marbled crayfish in combination with the spiny-cheek crayfish, the signal crayfish, the red swamp crayfish, and the Australian common yabby C. destructor, we conducted a set of independent laboratory experiments directly comparing their survival, growth, claw injury, and reproduction (glair gland formation, ovulation, and fecundity) since the onset of exogenous feeding. With this approach, we aim to investigate the effect of intra- vs. interspecific competition between marbled crayfish and other prominent well-established NICS on life-history traits, which may further affect the invasion success of these species. We hypothesize that the marbled crayfish as a relatively 'new' NICS will be able to outcompete other NICS counterparts because of its life-history strategy (parthenogenetic reproduction combined with early maturation and high fecundity). Given that these life-history traits are critical to understand how any population fares along with their potential to establish leading to a successful invasion, we considered such a comparative analysis as key in advancing our understanding of the mechanisms determining dominance of an invader in a new ecosystem.

\section{Materials and Methods}

\subsection{Origin of Experimental Animals and Selection of Juveniles}

Ovigerous females of spiny-cheek crayfish and signal crayfish were obtained from their established populations in the Czech Republic, Elbe River, Černěves $\left(50.462^{\circ} \mathrm{N}, 14.237^{\circ} \mathrm{E}\right)$, and Stržek pond, Kozlov $\left(49.378^{\circ} \mathrm{N}, 16.084^{\circ} \mathrm{E}\right)$, respectively, and were transported to the laboratory several weeks before hatching and gradually acclimatized to the experimental temperature. The remaining species originated from our laboratory cultures held at the Research Institute of Fish Culture and Hydrobiology, Vodňany, given their lack of wild populations in the country. The species in the laboratory culture were derived from local pet trade agents and were cultured for several generations under closed control conditions. Females of marbled crayfish and the respective counterparts were selected using those individuals with juveniles first reaching independence (i.e., those being on the onset of exogenous feeding) on the same day to ensure exact comparability of species performances in the experiment. Thus, the selection protocol did not allow the involvement of juveniles originating from females at different stages.

\subsection{Experimental Design}

In order to better understand how juveniles of different NICS perform when living in sympatry, we conducted a series of four independent pairwise laboratory experiments comparing growth, survival, claw injury, glair gland formation, ovulation, and fecundity of marbled crayfish and four prominent NICS (spiny-cheek crayfish, signal crayfish, common yabby, and red swamp crayfish) since the onset of exogenous feeding juvenile stage 2 in the signal crayfish and juvenile stage 3 in remaining species [42]. Each trial involving marbled crayfish and other NICS contained three experimental groups-two monocultures-one for each species, thereafter indicated as "single" stocks, and their communal stock with identical final stocking density and a species ratio 1:1 (thereafter indicated as "mixed" stock). The stocking density per aquarium, number of replications for all tested groups, duration of trials in weeks, and water temperature are shown Figure 1. Due to the limited number of offspring, initial stocking density and number of replications were lowered, especially in the trial involving the signal crayfish. In this trial, the initial weight of marbled crayfish juveniles is missing (we avoided initial stocking of weighed juveniles due to possible unnoticed injury prior the experiment; in other cases, we weighed a sample of 14 to 34 juveniles). All trials lasted 18 weeks, except for the trial with red swamp crayfish, 
which was terminated at 15 weeks due to earlier maturation of both tested species (see the Results section). The mean water temperature (registered hourly using Minikin loggers, Environmental Measuring Systems, Brno, Czech Republic) ranged from 21.5 to $22.1^{\circ} \mathrm{C}$ in all trials (Figure 1). Dissolved oxygen measured daily (Oxi 315i, WTW GmbH, Weilheim, Germany), was always above $7 \mathrm{mg} \cdot \mathrm{L}^{-1}$, usually exceeding $8 \mathrm{mg} \cdot \mathrm{L}^{-1}$ (saturation above $90 \%$ ). The daily monitored $\mathrm{pH}$ ( $\mathrm{pH} 315 \mathrm{i}, \mathrm{WTW} \mathrm{GmbH}$, Weilheim, Germany) was stable, ranging from 7.31 to 7.88 . The light:dark regime was $14: 10 \mathrm{~h}$, mimicking the light regime of the growing season.

(A)
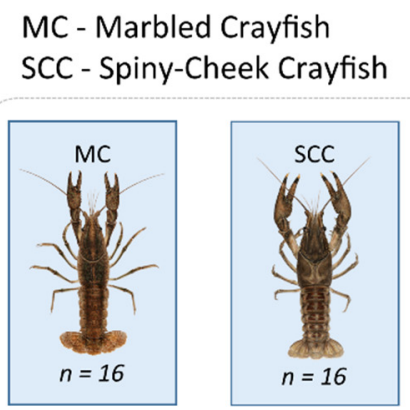

(C) MC - Marbled Crayfish
CY - Common Yabby
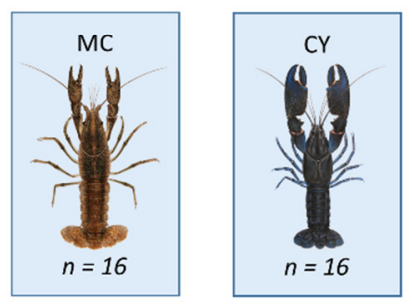

13 weeks

i. $21.5 \pm 0.3^{\circ} \mathrm{C}$

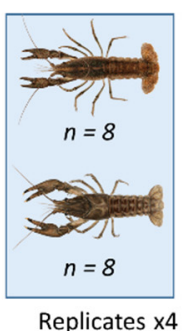

(3) 18 weeks

d. $21.7 \pm 0.3^{\circ} \mathrm{C}$

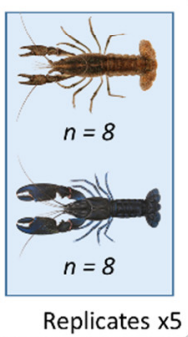

(B)

\section{MC - Marbled Crayfish SC - Signal Crayfish}

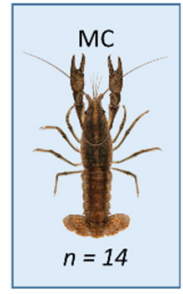

(D) MC - Marbled Crayfish
RSC - Red Swamp Crayfish

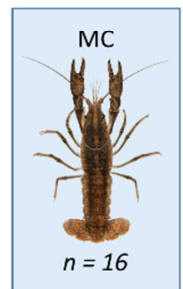

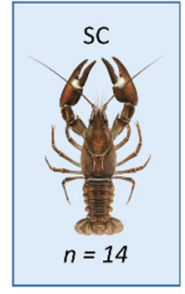

18 weeks i. $21.9 \pm 0.5^{\circ} \mathrm{C}$

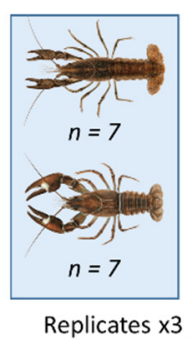

(3) 15 weeks

d. $22.1 \pm 0.3^{\circ} \mathrm{C}$

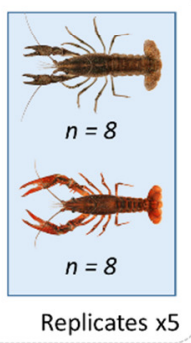

Figure 1. Experimental design and details of trials comparing survival, growth, claw injury, and reproduction of marbled crayfish (MC) vs. spiny-cheek crayfish (SCC, trial A), signal crayfish (SC, trial B), common yabby (CY, trial C), and red swamp crayfish (RSC, trial D) since the onset of exogenous feeding. Water temperature is presented as mean \pm SD. The duration of the experiment and replicates for each trial is also shown. Note that crayfish sizes are not scaled.

\subsection{Culturing Conditions and Feeding}

Unsexed juveniles were randomly stocked to the laboratory recirculating system with glass aquaria $(37 \mathrm{~cm}$ width $\times 55 \mathrm{~cm}$ length $\times 31.5 \mathrm{~cm}$ height, the usable volume of $55 \mathrm{~L}$ ) representing culture units (experimental details summarized in the Figure 1). To minimize aggression and cannibalism, shelters were provided by one fired clay brick $(6.5 \times 28.5$ $\times 13.5 \mathrm{~cm}$ ) with 39 cross holes ( 26 and 13 holes with a profile of $1 \times 3 \mathrm{~cm}$ and $1 \times 1 \mathrm{~cm}$, respectively) placed in each aquarium [43], i.e., the number of available individual shelters exceeded stocked juveniles more than twice at the beginning of the experiment. As the crayfish grew during the experiment, two blocks of joined polypropylene tubes, each containing five tubes (length $10 \mathrm{~cm}$, inner diameter $35 \mathrm{~mm}$ ), were added as larger shelters at six weeks of culture. The base of each block was represented by three longitudinallyjoined tubes with two further tubes positioned pyramidal in the second layer [44].

In all trials, crayfish were fed ad libitum daily by defrosted chironomid larvae and pond zooplankton for the first six weeks. Fresh plankton was obtained from a local pond when the particular trial started and kept frozen at $-20^{\circ} \mathrm{C}$ until utilization (see Table S1 for plankton species composition). After six weeks, this diet was altered to defrosted chironomid larvae and commercial pellets (Granugreen, Sera, Heinsberg, Germany). Aquaria were 
cleaned three times a week (Monday, Tuesday, and Friday). To minimize handling with the animals, individual dry weights (removal of excessive water on the absorbing tissue paper) were weighed every three weeks by using analytical balance (Kern \& Sohn $\mathrm{GmbH}$, Balingen, Germany) to the nearest $0.001 \mathrm{~g}$. On this occasion, animals were also checked for missing and regenerating claws. Once glair glands were noticed, the reproduction status of females was assessed weekly (presence of glair glands and number of eggs after detachment from pleopods by tweezers-both absolute and relative fecundities [per $\mathrm{mm}$ of carapace length] were analyzed).

\subsection{Statistical Analyses}

All data were assessed for normality and homoscedasticity using Kolmogorov-Smirnov and Levene's tests, respectively. Given the lack of test prerequisites (normality data and/or homoscedasticity in several groups), weights in single and mixed stocks were compared with non-parametric Kruskal-Wallis tests followed by multiple comparisons of mean ranks for all groups as a post-hoc test. Pairwise intraspecific comparisons (single vs. mixed stocks) in given trials and time were also evaluated using the non-parametric Mann-Whitney $\mathrm{U}$ test. Sex-intraspecific weight differences at the end of the trials were compared using Student's t-test in sexually reproducing species. The absolute and relative fecundity in single vs. mixed stocks of marbled crayfish were compared using Student's t-test as well. These analyses were performed in Statistica software 12.0 for Windows (StatSoft, Prague, Czech Republic). We used a non-parametric survival analysis (Kaplan-Meier method) using the 'survival' $R$ package [45] and tested for significant differences between specific pair assemblages. In addition, to assess the incidence of individuals with missing and/or regenerating claws (those individuals indicated as 1 ; intact animals considered as 0 ), we run generalized linear models with quasibinomial distribution due to overdispersion of data [46] followed by post-hoc tests to determine possible differences in the given assemblages through time and between groups (single and mixed stocks of tested species in the given time). For all statistical tests, $p$-values $<0.05$ were considered significant.

\section{Results}

\subsection{Growth Analysis}

The initial weight of the stocked juveniles at the onset of exogenous feeding varied greatly among species. At the juvenile stage 3 , the individual weight of marbled crayfish generally ranged between 5 and $6 \mathrm{mg}$, while spiny-cheek crayfish and red swamp crayfish were nearly twice as big ( $9.8 \pm 0.5$ and $9.9 \pm 1.2 \mathrm{mg}$, respectively) and common yabby three times as big $(15.2 \pm 1.0 \mathrm{mg})$. Although initial weight for marbled crayfish was not available in the trial with signal crayfish, based on the other trials, stocked signal crayfish at juvenile stage 2 would have been around four times bigger $(21.3 \pm 1.7 \mathrm{mg})$ than marbled crayfish at juvenile stage 3 (see Figure 1 for details).

Despite the apparent initial disadvantage of marbled crayfish in terms of size, it grew consistently faster than signal crayfish as well as spiny-cheek crayfish but not when compared to common yabby and red swamp crayfish (Figure 2). Except for the beginning of the trial with the spiny-cheek crayfish (week 3), significant interspecific differences in weight were always apparent. In general, species with faster growth tended to attain greater sizes in the mixed stocks when contrasted with their monocultures and vice versa, as indicated by the mean as well as individual weight data (Figure 2), but these differences were not usually significant. 
(A) Marbled crayfish vs. Spiny-cheek crayfish

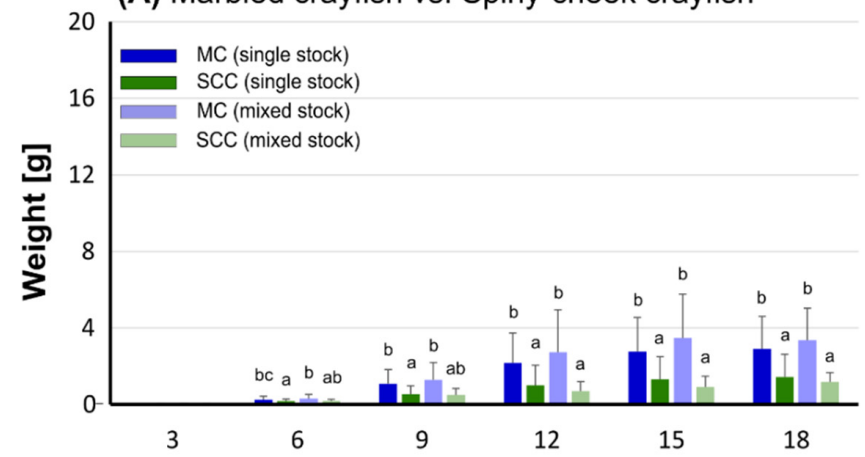

(B) Marbled crayfish vs. Signal crayfish

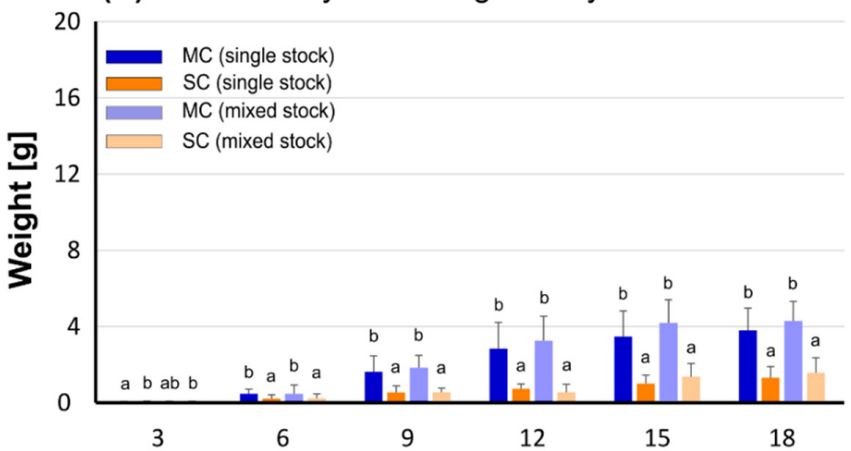

(C) Marbled crayfish vs. Common yabby

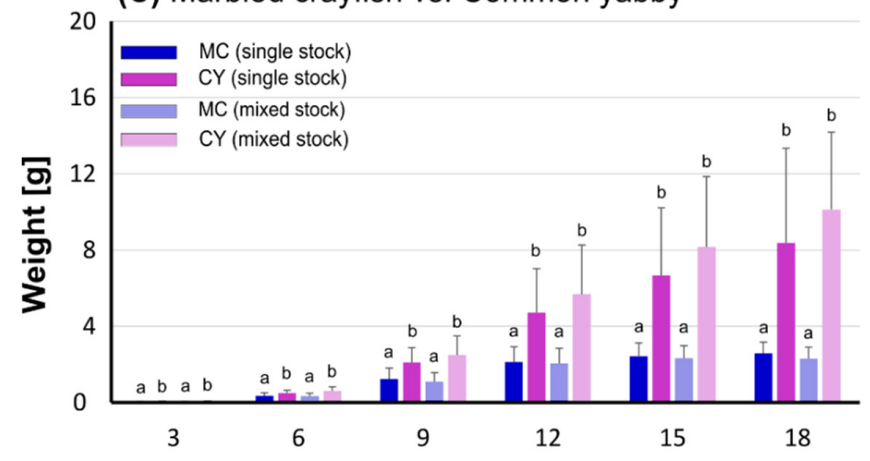

(D) Marbled crayfish vs. Red swamp crayfish

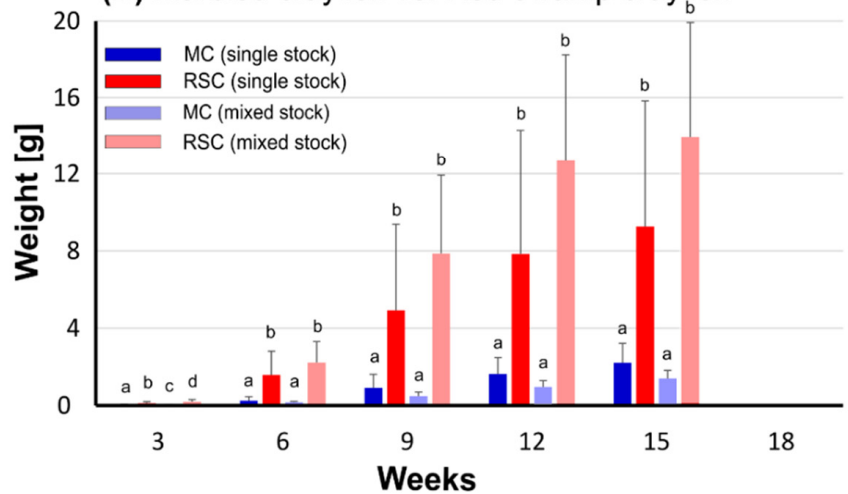

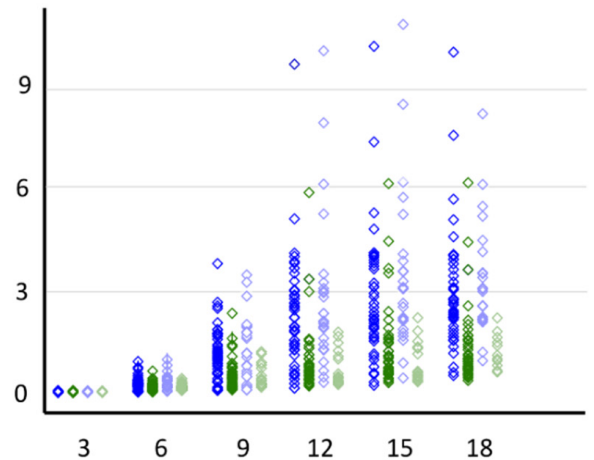
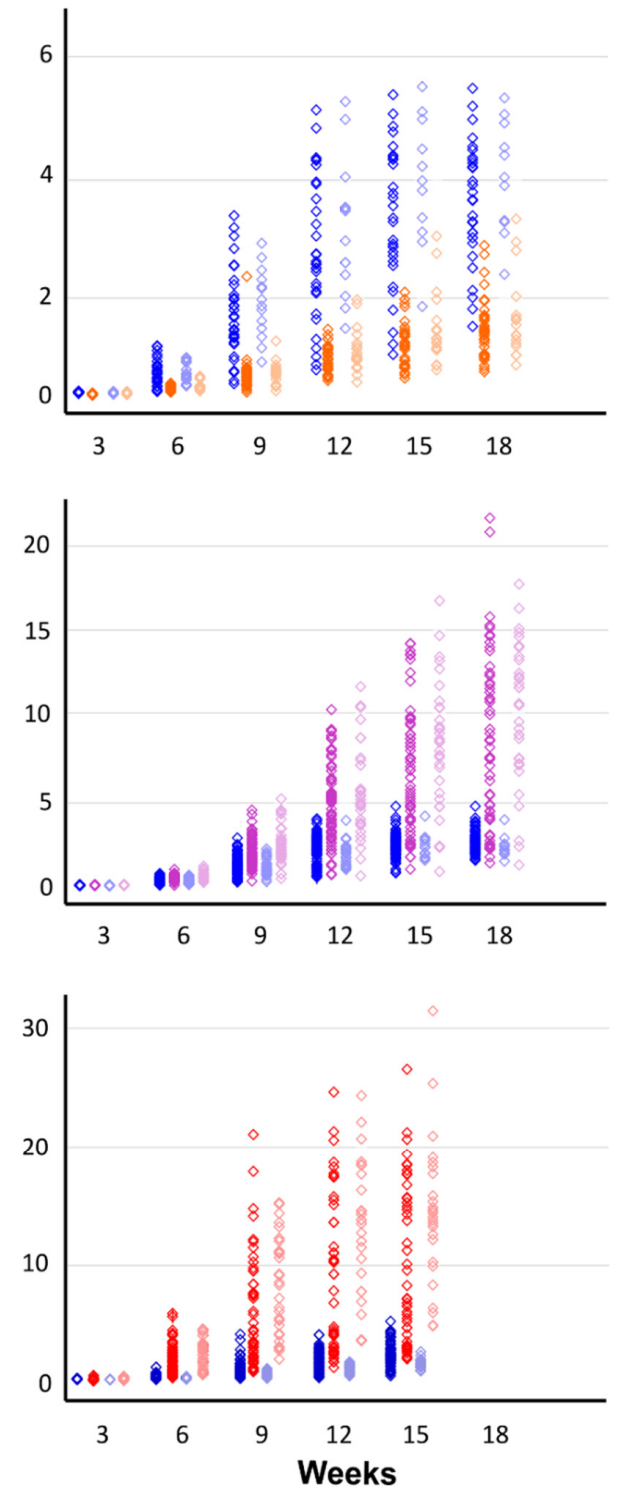

Figure 2. Weight (g) of marbled crayfish-MC in trials with spiny-cheek crayfish-SCC (A), signal crayfish-SC (B), common yabby-CY (C), and red swamp crayfish—RSC (D) kept in single-species and mixed stocks through the experiment (note that darker and lighter colors are used for single and mixed stocks, respectively). The left side of the figure panel represents the mean values $(+\mathrm{SD})$. Where applicable, differing letter superscripts $(a, a b, b, b c, c, d)$ indicate statistical differences (Kruskal-Wallis test, Multiple comparisons of mean ranks for all groups, $p<0.05$ ) among groups in the given time. Note the uniform scale of the Y-axis for better comparability of trials. The right side of the figure panel shows individual values with adjusted scales to better depict the intraspecific variabilities observed. 
Final maximum values of weight rarely exceeded $5 \mathrm{~g}$ in the marbled crayfish across all trials and were suppressed by the onset of female maturation and reproduction (see results below). Yet, individuals up to $10 \mathrm{~g}$ were noticed in the trial with spiny-cheek crayfish (the smallest species on average), whose individual weights varied largely in the single stock but not in the mixed stock. Signal crayfish, as well as marbled crayfish in the trials with common yabby and red swamp crayfish, respectively, were also relatively consistent in weight. At the experiments, common yabby and red swamp crayfish even exceeded 20 and $30 \mathrm{~g}$ after 18 and 15 weeks, respectively (Figure 2).

When considering sex-related weight differences in individuals surviving until the end (with the exception of parthenogenetic marbled crayfish), the mean absolute values of males were on average higher in all but one group — signal crayfish kept in single stock (Figure 3). However, significant differences were achieved only in the single stock of common yabby and mixed stock of red swamp crayfish (Figure 3).

\section{(A) Spiny-cheek crayfish}

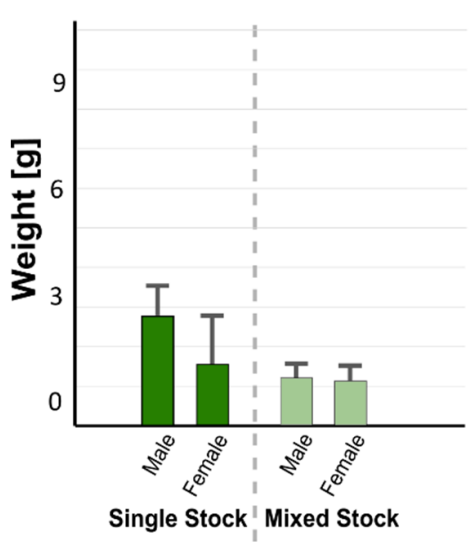

(B) Signal crayfish

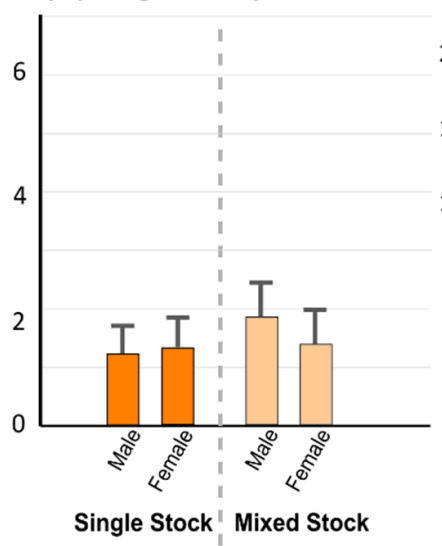

(C) Common yabby

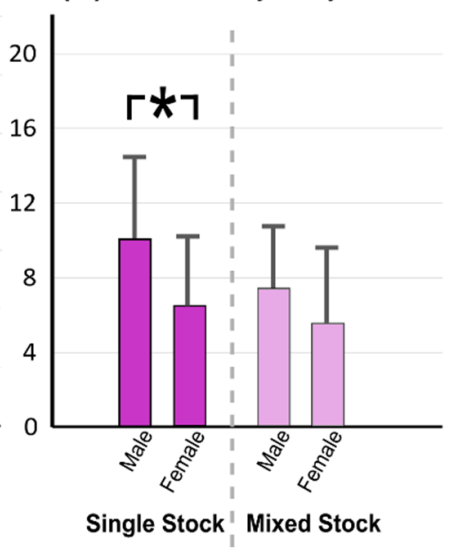

(D) Red swamp crayfish

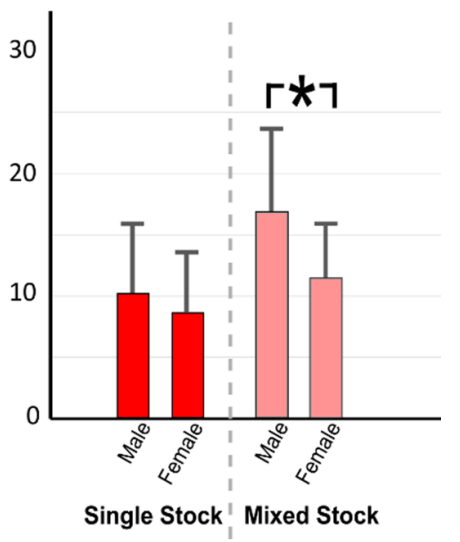

Figure 3. Sex-related final weight in sexually reproducing species (spiny-cheek crayfish (trial A), signal crayfish (B), common yabby $(\mathbf{C})$, and red swamp crayfish (D)) kept in single-species and mixed stocks. Asterisks $\left(^{*}\right)$ indicate significant difference between sexes in the given stock, Student's $t$-test, $p<0.05$.

\subsection{Survival Rate}

The final survival rates of marbled crayfish kept as single stocks ranged from $69 \%$ (trials with signal crayfish and spiny-cheek crayfish) to $91 \%$ (trial with common yabby). The lowest final survival was observed in the single stocks of spiny-cheek crayfish (59\%), followed by red swamp crayfish $(60 \%)$, while higher final survival was observed in the common yabby $(74 \%)$ and signal crayfish ( $83 \%$; see Figure S1). As derived from survival analyses modeling, we identified significant differences between the survival of NICS among all assemblages (Figure 4, for statistical values Table S2). Marbled crayfish generally expressed a higher survival rate over the experiment than the spiny-cheek crayfish, but had a lower survival rate compared to signal crayfish in mixed stocks. We found no significant differences between the survival rate of either of these NICS when grown in single stocks, nor between single and mixed stocks of either species. However, marbled crayfish expressed lower survival rates compared to the common yabby and red swamp crayfish when housed in mixed but not in single stocks. When in a mixed stock with common yabby, the marbled crayfish showed a significantly lower survival rate compared to its survival in single stock. Red swamp crayfish in the mixed stock expressed a significantly higher survival rate compared to its single stock (Figure 4, Table S2). 


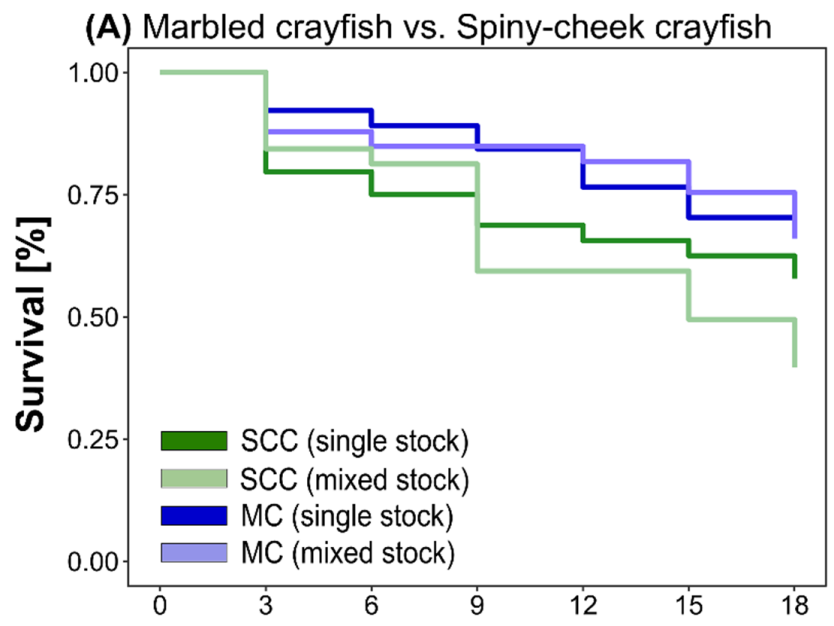

(B) Marbled crayfish vs. Spiny-cheek crayfish

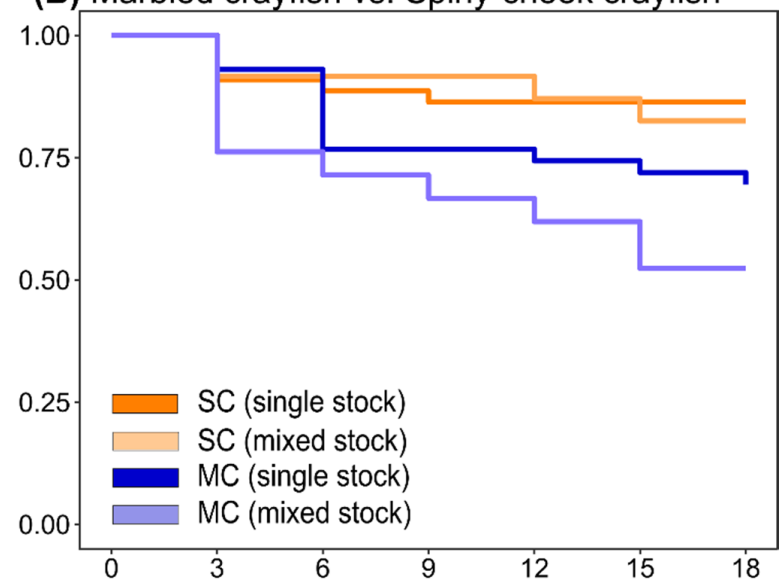

(D) Marbled crayfish vs. Red swamp crayfish

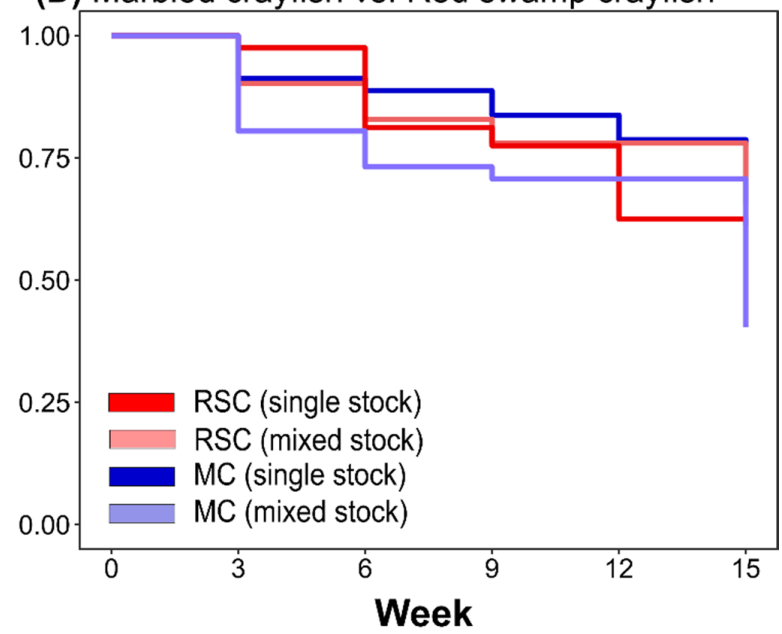

Figure 4. Kaplan-Meier survival analysis plots of marbled crayfish (MC) in trials with spiny-cheek crayfish (SCC) (A), signal crayfish—SC (B), common yabby-CY (C), and red swamp crayfish-RSC (D) kept in single-species and mixed stocks through the experiment (note that darker and lighter colors are used for single and mixed stocks, respectively).

\subsection{Missing and/or Regenerating Claws}

In all but one case (species assemblage in trial A with the spiny-cheek crayfish), the model outputs indicated significant differences in species assemblages, time, and their interactions in terms of claw injuries (Table S3). Overall, the incidence of claw injuries increased over time, with the exception of spiny-cheek crayfish in the single stock, and marbled crayfish in the mixed stock (trail with signal crayfish) as well as single stock (trial with common yabby) (see Table 1). Incidence of missing and/or regenerating claws did not exceed $20 \%$ in survivors within the single stocks of marbled crayfish, spiny-cheek crayfish, and signal crayfish, but was substantial in rapidly growing species with greater individual weight variance, resulting in up to $37 \%$ and $42 \%$ missing and/or regenerating claws in the common yabby and red swamp crayfish, respectively (Table 1). Marbled crayfish were less damaged in the mixed stocks with the signal crayfish and vice versa at weeks 15 and 18. More balanced situation occurred in the trial with spiny-cheek crayfish. On the other hand, marbled crayfish suffered up to $45 \%$ and $50 \%$ incidence in mixed stocks with common yabby and red swamp crayfish at the end of the trials, respectively, which in turn led to substantial but significantly fewer claw injuries (up to $22 \%$ and $35 \%$, respectively) compared to their single stocks (Table 1). 
Table 1. Incidence (\%) of individuals with missing and/or regenerating claws of marbled crayfish$\mathrm{MC}$ in trials with spiny-cheek crayfish-SCC (A), signal crayfish—SC (B), common yabby-CY (C), and red swamp crayfish-RSC (D) kept in single-species and mixed stocks through the experiment.

\begin{tabular}{|c|c|c|c|c|c|c|c|}
\hline \multirow[t]{2}{*}{ Trial } & \multirow[t]{2}{*}{ Group } & \multicolumn{6}{|c|}{ Week } \\
\hline & & 3 & 6 & 9 & 12 & 15 & 18 \\
\hline \multirow[t]{4}{*}{ A } & MC single & $0^{\mathrm{A}, \mathrm{a}}$ & $0^{\mathrm{A}, \mathrm{a}}$ & $2^{\mathrm{B}, \mathrm{a}}$ & $20^{\mathrm{C}, \mathrm{a}}$ & $11^{\mathrm{BC}, \mathrm{a}}$ & $9^{\mathrm{BC}, \mathrm{a}}$ \\
\hline & SCC single & $4^{\mathrm{A}, \mathrm{a}}$ & $6^{\mathrm{A}, \mathrm{a}}$ & $7^{\mathrm{A}, \mathrm{a}}$ & $2^{\mathrm{A}, \mathrm{a}}$ & $5^{\mathrm{A}, \mathrm{a}}$ & $11^{\mathrm{A}, \mathrm{a}}$ \\
\hline & MC mixed & $0^{\mathrm{A}, \mathrm{a}}$ & $0^{\mathrm{A}, \mathrm{a}}$ & $4^{\mathrm{B}, \mathrm{a}}$ & $8^{\mathrm{B}, \mathrm{a}}$ & $8^{\mathrm{B}, \mathrm{a}}$ & $10^{\mathrm{B}, \mathrm{a}}$ \\
\hline & SCC mixed & $0^{\mathrm{A}, \mathrm{a}}$ & $4^{\mathrm{B}, \mathrm{a}}$ & $11^{\mathrm{B}, \mathrm{a}}$ & $5^{\mathrm{B}, \mathrm{a}}$ & $20^{\mathrm{B}, \mathrm{a}}$ & $8^{\mathrm{B}, \mathrm{a}}$ \\
\hline \multirow[t]{4}{*}{ B } & MC single & $3^{\mathrm{B}, \mathrm{a}}$ & $0^{\mathrm{A}, \mathrm{a}}$ & $16^{\mathrm{B}, \mathrm{a}}$ & $6^{\mathrm{B}, \mathrm{a}}$ & $3^{B, b}$ & $14^{\mathrm{B}, \mathrm{bc}}$ \\
\hline & SC single & $0^{\mathrm{A}, \mathrm{a}}$ & $3^{\mathrm{B}, \mathrm{a}}$ & $3^{\mathrm{B}, \mathrm{a}}$ & $3^{\mathrm{B}, \mathrm{a}}$ & $3^{B, b}$ & $3^{B, b}$ \\
\hline & MC mixed & $0^{\mathrm{A}, \mathrm{a}}$ & $0^{\mathrm{A}, \mathrm{a}}$ & $0^{\mathrm{A}, \mathrm{a}}$ & $0^{\mathrm{A}, \mathrm{a}}$ & $0^{\mathrm{A}, \mathrm{a}}$ & $0^{\mathrm{A}, \mathrm{a}}$ \\
\hline & SC mixed & $0^{\mathrm{A}, \mathrm{a}}$ & $0^{\mathrm{A}, \mathrm{a}}$ & $0^{\mathrm{A}, \mathrm{a}}$ & $11^{\mathrm{B}, \mathrm{a}}$ & $35^{\mathrm{BC}, \mathrm{c}}$ & $53^{C, c}$ \\
\hline \multirow[t]{4}{*}{$\mathrm{C}$} & MC single & $1^{\mathrm{A}, \mathrm{a}}$ & $1^{\mathrm{A}, \mathrm{a}}$ & $7^{\mathrm{A}, \mathrm{a}}$ & $5^{\mathrm{A}, \mathrm{a}}$ & $5^{\mathrm{A}, \mathrm{a}}$ & $4^{\mathrm{A}, \mathrm{a}}$ \\
\hline & CY single & $0^{\mathrm{A}, \mathrm{a}}$ & $4^{\mathrm{B}, \mathrm{a}}$ & $8^{\mathrm{BC}, \mathrm{a}}$ & $13^{\mathrm{BC}, \mathrm{a}}$ & $24^{C D, b}$ & $37^{\mathrm{D}, \mathrm{b}}$ \\
\hline & MC mixed & $0^{\mathrm{A}, \mathrm{a}}$ & $3^{\mathrm{B}, \mathrm{a}}$ & $2^{\mathrm{B}, \mathrm{a}}$ & $42^{C, b}$ & $23^{B C}, a b$ & $45^{\mathrm{C}, \mathrm{b}}$ \\
\hline & CY mixed & $0^{\mathrm{A}, \mathrm{a}}$ & $10^{\mathrm{B}, \mathrm{a}}$ & $5^{\mathrm{B}, \mathrm{a}}$ & $14^{\mathrm{B}, \mathrm{ab}}$ & $16^{\mathrm{B}, \mathrm{ab}}$ & $22^{\mathrm{B}, \mathrm{ab}}$ \\
\hline \multirow[t]{4}{*}{$\mathrm{D}$} & MC single & $0^{\mathrm{A}, \mathrm{a}}$ & $3^{\mathrm{B}, \mathrm{a}}$ & $6^{\mathrm{B}, \mathrm{a}}$ & $2^{\mathrm{B}, \mathrm{a}}$ & $3^{\mathrm{B}, \mathrm{a}}$ & NA \\
\hline & RSC single & $0^{\mathrm{A}, \mathrm{a}}$ & $8^{\mathrm{B}, \mathrm{a}}$ & $23^{B C, a}$ & $32^{C, b}$ & $42^{C, b}$ & NA \\
\hline & MC mixed & $3^{\mathrm{A}, \mathrm{a}}$ & $3^{\mathrm{AB}, \mathrm{a}}$ & $18^{\mathrm{AB}, \mathrm{a}}$ & $13^{\mathrm{AB}, \mathrm{ab}}$ & $50^{B, b}$ & NA \\
\hline & RSC mixed & $0^{\mathrm{A}, \mathrm{a}}$ & $0^{\mathrm{A}, \mathrm{a}}$ & $13^{\mathrm{B}, \mathrm{a}}$ & $14^{\mathrm{B}, \mathrm{ab}}$ & $35^{C, b}$ & NA \\
\hline
\end{tabular}

Upper indices denote differences in the given assemblages over time (uppercase letters) and between groupssingle and mixed stocks of species analyzed - in the given time (lowercase letters), using GLM with quasi-binomial distribution followed by post-hoc tests, $p<0.05$.

\subsection{Speed of Maturation and Fecundity Rates}

Development of glair glands was first noticed in the marbled crayfish (week 11; an accidental finding out of regular weighing scheme) followed by red swamp crayfish (week 12), spiny-cheek crayfish (week 13), and common yabby (week 15). No glair glands were found in signal crayfish (Table 2). In general, glair gland formation followed a pattern of earlier onset and/or more rapid development when the species was superior in weight, as in the case of marbled crayfish mixed stocks in trials with the spiny-cheek crayfish and signal crayfish, or common yabby and red swamp crayfish when kept with marbled crayfish. In these cases, animals tended to perform better than their respective monocultures (considering that observed values in mixed stocks are derived from lower absolute numbers of stocked animals). These patterns were also pronounced in reproduction performance of marbled crayfish, the only species which laid eggs in our experiment. While not statistically significant, its absolute and relative pleopodal fecundities tended to be higher when cultured together with signal crayfish (increased by $25 \%$ and $16 \%$, respectively) and spiny-cheek crayfish (12\% and $9 \%$, respectively) (Table 2). Only a slight reduction (decline by 4 and $5 \%$, respectively) was observed when kept together with the common yabby. Additionally, no marbled crayfish laid eggs when kept together with the superior red swamp crayfish (Table 2). Red swamp crayfish mated regularly at the end of the experiment (week 15). 
Table 2. Number of females with developed glair glands and with eggs throughout the experiment (note that absolute numbers of evaluated individuals vary; additionally, females with detached eggs miss glair glands in the following time period). Marbled crayfish (MC) in trials with spiny-cheek crayfish—SCC (A), signal crayfish—SC (B), common yabby-CY (C), and red swamp crayfish-RSC (D) kept in single-species and mixed stocks.

\begin{tabular}{|c|c|c|c|c|c|c|c|c|c|c|c|}
\hline \multirow[t]{2}{*}{ Trial } & \multirow[t]{2}{*}{ Group } & \multicolumn{8}{|c|}{ Week } & \multicolumn{2}{|c|}{ Fecundity } \\
\hline & & 11 & 12 & 13 & 14 & 15 & 16 & 17 & 18 & Absolute & Relative \\
\hline \multirow{4}{*}{ A } & MC single & - & - & $3+0$ & $13+0$ & $15+0$ & $15+8$ & $17+3$ & $10+12$ & $134 \pm 66$ & $5.5 \pm 2.0$ \\
\hline & SCC single & - & - & $1+0$ & $2+0$ & $3+0$ & $3+0$ & $3+0$ & $3+0$ & - & - \\
\hline & MC mixed & - & $1+0$ & $1+0$ & $9+0$ & $9+0$ & $11+2$ & $10+2$ & $8+5$ & $150 \pm 65$ & $6.0 \pm 1.9$ \\
\hline & SCC mixed & - & - & - & - & $1+0$ & $1+0$ & $1+0$ & $1+0$ & - & - \\
\hline \multirow{4}{*}{ B } & MC single & - & - & - & - & $5+0$ & $11+1$ & $16+2$ & $12+6$ & $220 \pm 82$ & $8.6 \pm 2.8$ \\
\hline & SC single & - & - & - & - & - & - & - & - & - & - \\
\hline & MC mixed & - & - & - & - & $3+0$ & $7+0$ & $4+0$ & $6+4$ & $275 \pm 50$ & $10.0 \pm 1.6$ \\
\hline & SC mixed & - & - & - & - & - & - & - & - & - & - \\
\hline \multirow{4}{*}{$\mathrm{C}$} & MC single & $8+0$ & $18+0$ & $21+0$ & $39+0$ & $29+19$ & $24+17$ & $14+17$ & $11+2$ & $131 \pm 42$ & $6.1 \pm 1.8$ \\
\hline & CY single & - & - & - & - & $5+0$ & $16+0$ & $14+0$ & $8+0$ & - & - \\
\hline & MC mixed & - & $1+0$ & $6+0$ & $8+0$ & $8+0$ & $7+5$ & $5+2$ & $2+2$ & $126 \pm 39$ & $5.8 \pm 1.4$ \\
\hline & CY mixed & - & - & - & - & $4+0$ & $9+0$ & $9+0$ & $9+0$ & - & - \\
\hline \multirow{4}{*}{$\mathrm{D}$} & MC single & - & $11+0$ & $17+0$ & $17+1$ & $9+8$ & NA & NA & NA & $126 \pm 32$ & $6.1 \pm 1.0$ \\
\hline & RSC single & - & $1+0$ & $3+0$ & $5+0$ & $3+0$ & NA & NA & NA & - & - \\
\hline & MC mixed & - & $1+0$ & $1+0$ & $0+0$ & $0+0$ & NA & NA & NA & - & - \\
\hline & RSC mixed & - & $3+0$ & $6+0$ & $8+0$ & $8+0$ & NA & NA & NA & - & - \\
\hline
\end{tabular}

The last columns indicate absolute and relative (per mm of carapace length) pleopodal fecundity presented as mean $\pm \mathrm{SD}$. Fecundity did not differ significantly between single and mixed stocks of marbled crayfish in evaluated indices (Student's $t$-test, $p<0.05$ ).

\section{Discussion}

Growth and survival rates, speed of maturation, mode of reproduction, and fecundity are among the principal life history traits determining the success of any species $[31,47,48]$. These attributes are often of special interest when indigenous and non-indigenous species interact, or when more non-indigenous (and potentially invasive) species co-occur, possibly resulting in the disappearance of one species. For instance, several populations of European ICS have been lost, and many more have been substantially reduced, largely due to the direct or indirect effects of NICS [22,23]. This is because introduced freshwater crayfish often exhibit invasive behavior in their non-native ranges [49]. As the number of NICS gradually increases in the European continent, and their ranges expand, new sympatric populations steadily appear $[34,40,50]$. Unlike between native and invasive crayfish species, the interactions between NICS when these co-occur are not yet well understood.

\subsection{Intra- and Interspecific Growth and Survival Rates in Single and Mixed Stocks}

Despite being the smallest at the onset of exogenous feeding generally between 5 to $6 \mathrm{mg}$ [51], marbled crayfish was capable to outgrow spiny-cheek crayfish and signal crayfish but not common yabby and especially not red swamp crayfish, which grew substantially faster than marbled crayfish. While usually not significantly different, fastergrowing species tended to attain greater sizes in the mixed stocks when compared to their monocultures and vice versa. Our results suggest substantial interspecific differences in the growth rates, but also a role of different intraspecific stocking densities of the species-greater sizes of the faster growing species (e.g., common yabby and red swamp crayfish) can be more easily achieved in the mixed stock with a smaller counterpart e.g., marbled crayfish (and thus lowered intraspecific interactions) when compared with their monoculture. Males tended to attain greater weight than females, as expected in crayfish species [52].

The marbled crayfish is a middle-sized species with high growth potential under favorable conditions. Its laboratory stocks as well as wild populations usually do not exceed $10 \mathrm{~cm}$ of total body length $(\sim 20 \mathrm{~g})$. Larger size classes (e.g., up to $12-13 \mathrm{~cm}) \mathrm{can}$ 
be found in wild populations [50,53], but the abundance of such size classes is typically low [54-57]. In our study, final weight rarely exceeded $5 \mathrm{~g}(\sim 6 \mathrm{~cm}$ total body length) with the greatest values of $10 \mathrm{~g}$, corresponding to $\sim 7.5 \mathrm{~cm}$ total body length [58], achieved in the trial with the spiny-cheek crayfish. The growth rate of marbled crayfish was hampered by its early maturation and frequent reproduction with the onset of glair gland formation commonly seen since week 12 in our experiment. The spiny-cheek crayfish was on average the smallest species in our trials when compared to the marbled crayfish, where individual weight varied largely in the single stock but not the mixed stock, presumably suppressed by the presence of larger marbled crayfish. Similar to the marbled crayfish, the spinycheek crayfish is also a middle-sized species that typically does not exceed 9 to $10 \mathrm{~cm} \mathrm{[52],}$ although individuals with a body length reaching $13 \mathrm{~cm}$ have also been reported [59,60]. A small portion of fast-growing individuals can achieve 4 to $5 \mathrm{~cm}$ at the end of their first growing season [31]. This concurs with our results, with the largest animal weighing more than $6 \mathrm{~g}$, corresponding to $\sim 6 \mathrm{~cm}$ of total body length. The signal crayfish is a rather large crayfish species with females and males measuring up to $12 \mathrm{~cm}$ and $16 \mathrm{~cm}$, respectively. Yet, the upper weight limit can be considerable, ranging from 200 to $250 \mathrm{~g}$ [61-63]. Westman et al. [64] reported the mean size of juveniles at the end of their first season to reach $3 \mathrm{~cm}$, noting though that it may differ among populations. For example, Abrahamsson [65] reported a size of $4 \mathrm{~cm}$ for one-year-old crayfish. This is concomitant with our data, where several individuals exceeded a weight of $2.5 \mathrm{~g}(>4 \mathrm{~cm})$.

The common yabby is a relatively large species, with a total body length usually not exceeding $15 \mathrm{~cm}$ and a weight of $150 \mathrm{~g}$. However, individuals weighing up to $350 \mathrm{~g}$ can rarely be observed [61]. In our study, the species successfully exceeded $20 \mathrm{~g}$ in 18 weeks; thus, it is not surprising that this warm-water species is of great interest to crayfish aquaculture $[66,67]$. However, global crayfish aquaculture is mostly focused on the red swamp crayfish $[68,69]$. Its total body length usually ranges from 10 to $12 \mathrm{~cm}$, but can reach up to $20 \mathrm{~cm}$ in exceptional cases [61]. Its growing potential is enormous compared to the aforementioned species, almost doubling its weight on average every three weeks when kept in single stocks, or even quadrupling its weight from week 6 to 9 in mixed stocks. In fact, juveniles can reach $50 \mathrm{~g}$ in just three to five months [23], which coincides with our findings of one animal exceeding $30 \mathrm{~g}$ within just 15 weeks. Laboratory experiments indicated similar behavioral competencies of both species in interactions when similar-sized individuals were compared. However, the red swamp crayfish seems superior, primarily owing to its greater growth rates and size achieved at adulthood. Recent research suggests a superior position of the red swamp crayfish at sympatric localities [34] as well as enhanced predation on the marbled crayfish [40].

Despite the standardization among conducted trials, these should be primarily considered as pairwise comparisons with the marbled crayfish, given that this species performed differently in the evaluated indices through trials. For instance, the composition of the plankton provided varied, so its replacement with a more standardized fresh diet is advised in future studies for better comparability (e.g., Artemia sp. nauplii). A key factor in the growth of crustaceans, and crayfish in particular, is temperature. An increase of temperature normally accelerates growth by shortening the inter-molt period and raising the frequency of molting $[70,71]$. Despite keeping the temperature constant in our experiments, different intra- and interspecific growth patterns were identified. It is well demonstrated that growth and life-history traits of those warm-water crayfish species (i.e., common yabby and red swamp crayfish) are more likely to push the limits of $r$-type strategies, while those from colder waters (i.e., spiny-check and signal crayfish) do so to a lesser extent [72]. Our results not only support the dominance of marbled crayfish over rather cold-water species when cohabiting, and vice versa over typically warm-water species, but also the large intraspecific variability in growth rate.

Survival rates developed in close relation with the growth performance discussed earlier. The faster-growing species usually tended to reach a higher survival rate in the mixed stocks when compared with their monocultures (because of lower intraspecific 
density in the defined culturing conditions), while survival of the smaller counterpart was negatively impaired. An interesting situation developed in the trial with signal crayfish, which, regardless of its smaller size, retained a very high survival rate. This can be explained by the presumed space segregation when signal crayfish occupied smaller shelters in bricks which larger marbled crayfish could not enter effectively. It can be presumed that a shortage in critical resources such as shelters and food would result in the reduced survival of signal crayfish as well.

\subsection{Incidence of Missing and/or Regenerating Claws}

Adding to the context of growth and survival rates, it is important to discuss the incidence of missing and/or regenerating claws as a consequence of individual interactions. Aggressiveness has often been associated with the success of invasive species, as well as with enhancing their competitiveness in a novel environment, hence helping them expand in their invaded range [73,74]. In our case, the incidence of missing and/or regenerating claws was relatively low in single stocks of marbled crayfish, spiny-cheek crayfish, and signal crayfish, but it was substantial in fast-growing species with a broad individual weight variability. Importantly, the presence of superior species in terms of growth in the mixed stock resulted in a greater injury rate of smaller counterparts and vice versa. These results are partially supported by previous studies, which showed that, in general, the marbled crayfish is less aggressive than other invasive species, such as the signal crayfish or the common yabby [75], but it may compete with the red swamp crayfish in equal-sized pairings [76,77]. We consider the mere weight contribution of missing and/or regeneration claws to the total weight presented, of secondary importance in the context of this study, and instead highlight the importance of the magnitude of different interspecific growth rates in the evaluated species. Notably, claws are important for mating, defense against predators, intra- and interspecific interactions, capture and manipulation of prey, burrowing, and carrying sensory structures in males that aid in the discrimination and localization of the female scent. Once injured, an animal is at greater risk of further damage and its fitness is reduced [78]. While demanding, regeneration of body appendages is well developed in crayfish [79], largely accompanied with molting. However, each molting needs to be weighed with an increased risk of natural mortality, predation, and cannibalism during this vulnerable period (note the high survival of slow-growing signal crayfish discussed earlier, i.e., lowered molting-related mortality).

\subsection{Speed of Maturation and Fecundity Rates}

Freshwater crayfish develop glair glands on the underside of the pleon prior to spawning, producing a mucus that, among others, aids in fertilization and attachment of the eggs to the pleopods [80]. The presence of glair glands was first observed in the single stock of the marbled crayfish species in the trial with common yabby at week 11 (the regular methodological time frame presumed control at week 12). The number of animals with developed glair glands (eight females) suggests that they might first appear even earlier in the species. A similar situation is also possible for the red swamp crayfish at week 12 with 11 and 3 females carrying glair glands in the single and mixed stock, respectively.

The marbled crayfish is the only species in our experiment that ovulated eggs, first seen in its monoculture when compared with the red swamp crayfish at week 14 (98 days) and from week 16 onwards in mixed stocks. If we presume that stages 1 and 2 lasted 12 days in our culturing conditions [81], it corresponds to ovulation at 110 days and possibly earlier, considering the frequency of controls. This is a month earlier than previously reported for this species-Seitz et al. [82] referred to females first reproducing at 141 to 255 days (30 weeks on average) when kept at $20-25{ }^{\circ} \mathrm{C}$. Similar to survival and incidence of missing and/or regenerating claws, onset and dynamics of glair gland formation (as well as first ovulation and fecundity in the marbled crayfish) were related with the weight of assessed species in the mixed stocks. The marbled crayfish was most suppressed when cultured together with the red swamp crayfish, where only one female with glair glands was 
observed (and did not manage to ovulate eggs). Both marbled crayfish and red swamp crayfish are highly fecund species. Marbled crayfish usually carry 50 to 200 eggs, while larger females can have up to 400 eggs $[58,83]$. In the wild though, it is possible to find females carrying around 700 eggs $[53,56,84]$. Fecundity of red swamp crayfish typically ranges from 200 to 300 eggs but can reach up to 700 eggs [85-87].

Based on body proportions and formation of copulatory stylets (gonopods) in males, form I males and females of spiny-cheek crayfish, i.e., those that are sexually active [88,89], were first noticed at week 12 . The first female with glair glands appeared a week later. A part of spiny-cheek crayfish individuals in populations can mature at the end of their first growing season, exhibiting presence of glair glands as well as mating behavior. Egg laying occurs in the next spring [31] with a commonly observed fecundity below 250 eggs, but potentially exceeding 500 eggs in exceptional cases [59,90,91]. In contrast, young-of-theyear marbled crayfish can theoretically reproduce in late summer/early autumn in the wild. The proportion of such females and the performance of this new generation during winter in temperate climates is unknown [53,92]. Signal crayfish generally reaches maturity in their second to third year at sizes ranging from 6 to $9 \mathrm{~cm}$ [63] and males typically mature one year earlier than females $[65,93,94]$. Its fecundity ranges between 100 to 400 eggs, but some females can have more than 500 eggs [94,95]. In this context, achieving maturation is comparatively a considerable disadvantage of this species compared to the other species examined in this study. However, it is substantially larger in adulthood and prefers colder localities. Competitiveness of marbled crayfish under such circumstances is worth further investigation.

Common yabby matures at a weight of about $20 \mathrm{~g}(\sim 9 \mathrm{~cm})$ and an age of less than one year. Under suitable conditions (water temperature of at least 18 to $20^{\circ} \mathrm{C}$ and a photoperiod over $14 \mathrm{~h}$ ), it is able to reproduce up to five times per year $[32,96,97]$, usually carrying 300 to 500 eggs [98,99], but can reach up to 1400 eggs in large females [66]. We observed formation of glair glands even in smaller females $(<8 \mathrm{~cm})$ since week 15 . While mortality might be a contributing factor, the number of females with glairs glands stayed stable in the mixed stock and declined in the single culture later on. This suggests that maturity can be achieved very rapidly, but our culturing conditions did not support reproduction of the species in our experiment. The red swamp crayfish is a typical $r$-strategist reaching maturity at an age of 4 to 5 months and a body length of less than $4.5 \mathrm{~cm}[32,100]$. This species is also highly fecund and two generations per year can emerge [85,101]. We observed females with glair glands as early as week 12 . At the termination of the experiment (week 15), mating behavior was common, but did not result in oviposition. Similar to the formation of glair glands in the common yabby above, it seems that the provided conditions were not suitable for completion of reproduction of these species. Yet, speed of maturation and fecundity of the red swamp crayfish was found to be very similar to that of marbled crayfish.

\section{Conclusions}

The growth rate, interaction dynamics and, in general, the life history traits of introduced species play a key role in their invasion success. Nowadays, with the increasing number of introductions, the overlap of several invasive populations is becoming more and more frequent; however, the effects of this overlap remain poorly understood. Our results show that, while greater growth of the parthenogenetic marbled crayfish occurs when it is present together with rather cold-water invasive species (signal crayfish and spiny-cheek crayfish), it is suppressed when co-occurring with typically warm-water invasive species, such as the common yabby and red swamp crayfish. Similarly, although the single stock survival rate of the marbled crayfish is generally high, its survival rate decreased sharply when cultured with fast-growing warm-water species. These results could be directly related to the incidence of claw loss and regeneration. Furthermore, despite its smaller size, the marbled crayfish reaches maturation earlier, which may represent a trade-off between growth and maturation speed in this species. When specifically contrasted with the sig- 
nal crayfish, early maturation and high fecundity benefit the marbled crayfish to a great extent; however, a role of signal crayfish size at adulthood will certainly be important in their interspecific interactions. Additionally, studying the described relationships at lower temperatures representing colder localities is of great interest, as these might suit better the requirements of both spiny-cheek crayfish and signal crayfish. These experimental studies would emphasize the importance of understanding how invasive species cope with their invasive interspecific when their populations overlap under different environmental conditions. Such insights could have important implications for predicting the spread of invasive populations as well as better understanding the outcome of overlaps that may occur in the future when new emerging invasive species are introduced, thus prioritizing management efforts.

Supplementary Materials: The following are available online at https:/ /www.mdpi.com/article/10 $.3390 /$ biology10050422/s1, Table S1. The estimated share of abundances of planktonic organisms provided to crayfish compared to marbled crayfish during the first six weeks of experimental trials, Table S2. The output of the Kaplan-Meier survival analysis of marbled crayfish-MC in trials with spiny-cheek crayfish —SCC (A), signal crayfish—SC (B), common yabby-CY (C), and red swamp crayfish - RSC (D) kept in single-species and mixed stocks through the experiment, Table S3. The output of the GLM with quasibinomial distribution on the incidence of individuals with missing and/or regenerating claws of marbled crayfish - in trials with spiny-cheek crayfish $-\mathrm{A}$, signal crayfish $-\mathrm{B}$, common yabby $-\mathrm{C}$, and red swamp crayfish $-\mathrm{D}$ kept in tested assemblages through the experiment, Figure S1. Survival (\%) of marbled crayfish-MC in trials with spiny-cheek crayfishSCC (A), signal crayfish—SC (B), common yabby-CY (C), and red swamp crayfish—RSC (D) kept in single-species and mixed stocks through the experiment (note darker and lighter colors used for single and mixed stocks, respectively).

Author Contributions: Conceptualization, A.K. and M.B. (Miloš Buřič); methodology, A.K., M.B. (Miloš Buřič) and M.B. (Martin Bláha); validation, M.B. (Miloš Buřič) and J.P.; formal analysis, A.K., P.J.H., F.J.O. and L.V.; investigation, A.K., M.B. (Miloš Buřič), M.B. (Martin Bláha), B.L., J.K., H.N.; resources, A.K.; data curation, A.K.; writing—original draft preparation, A.K., P.J.H., F.J.O. and L.V.; writing—review and editing, A.K., P.J.H., F.J.O. and L.V.; visualization, A.K., P.J.H., F.J.O. and L.V.; supervision, A.K.; project administration, A.K.; funding acquisition, A.K. All authors have read and agreed to the published version of the manuscript.

Funding: This research was funded by the Czech Science Foundation (No. 19-04431S). F.J.O. was funded by the Regional Government of Andalusia (Excelencia project P12-RNM 936). J.P. was supported by the Technology Agency of the Czech Republic within the project "DivLand" (SS02030018).

Institutional Review Board Statement: Not applicable.

Informed Consent Statement: Not applicable.

Data Availability Statement: The data that support the findings of this study are available from the corresponding author upon reasonable request.

Acknowledgments: We thank Melina Kourantidou and Ross N. Cuthbert for their valuable comments on an earlier version of the manuscript.

Conflicts of Interest: The authors have no conflict of interest to declare.

\section{References}

1. Pyšek, P.; Bacher, S.; Chytrý, M.; Jarošík, V.; Wild, J.; Celesti-Grapow, L.; Gassó, N.; Kenis, M.; Lambdon, P.W.; Nentwig, W.; et al. Contrasting patterns in the invasions of European terrestrial and freshwater habitats by alien plants, insects and vertebrates. Glob. Ecol. Biogeogr. 2010, 19, 317-331. [CrossRef]

2. Hanafiah, M.M.; Leuven, R.S.E.W.; Sommerwerk, N.; Tockner, K.; Huijbregts, M.A.J. Including the introduction of exotic species in life cycle impact assessment: The case of inland shipping. Environ. Sci. Technol. 2013, 47, 13934-13940. [CrossRef]

3. Seebens, H.; Essl, F.; Dawson, W.; Fuentes, N.; Moser, D.; Pergl, J.; Pyšek, P.; van Kleunen, M.; Weber, E.; Winter, M. Global trade will accelerate plant invasions in emerging economies under climate change. Glob. Chang. Biol. 2015, 21, 4128-4140. [CrossRef]

4. Seebens, H.; Blackburn, T.M.; Dyer, E.E.; Genovesi, P.; Hulme, P.E.; Jeschke, J.M.; Pagad, S.; Pyšek, P.; Winter, M.; Arianoutsou, M. No saturation in the accumulation of alien species worldwide. Nat. Commun. 2017, 8, 14435. [CrossRef]

5. Cohen, A.N.; Carlton, J.T. Accelerating invasion rate in a highly invaded estuary. Science 1998, 279, 555-558. [CrossRef] 
6. Ricciardi, A.; Blackburn, T.M.; Carlton, J.T.; Dick, J.T.; Hulme, P.E.; Iacarella, J.C.; Jeschke, J.M.; Liebhold, A.M.; Lockwood, J.L.; MacIsaac, H.J. Invasion science: A horizon scan of emerging challenges and opportunities. Trends Ecol. Evol. 2017, 32, 464-474. [CrossRef]

7. Patoka, J.; Prabowo, R.E.; Petrtýl, M.; Reynolds, J.D.; Kuř́iková, P.; Zámečníková-Wanma, B.P.; Kalous, L. Marine hitchhikers: A preliminary study on invertebrates unintentionally transported via the international pet trade. NeoBiota 2020, 61, 33. [CrossRef]

8. Jeschke, J.M.; Pyšek, P. Tens Rule. In Invasion Biology: Hypotheses and Evidence; Jeschke, J.M., Heger, T., Eds.; CAB International: Wallingford, UK, 2018; pp. 124-132.

9. Allendorf, F.W.; Lundquist, L.L. Introduction: Population biology, evolution, and control of invasive species. Conserv. Biol. 2003, 17, 24-30. [CrossRef]

10. Cuthbert, R.N.; Pattison, Z.; Taylor, N.G.; Verbrugge, L.; Diagne, C.; Ahmed, D.A.; Leroy, B.; Angulo, E.; Briski, E.; Capinha, C.; et al. Global economic costs of aquatic invasive alien species. Sci. Total Environ. 2021, 775, 145238. [CrossRef] [PubMed]

11. Diagne, C.; Leroy, B.; Vaissière, A.-C.; Gozlan, R.E.; Roiz, D.; Jarić, I.; Salles, J.-M.; Bradshaw, C.J.; Courchamp, F. High and rising economic costs of biological invasions worldwide. Nature 2021, 1-6. [CrossRef]

12. Strayer, D.L. Alien species in fresh waters: Ecological effects, interactions with other stressors, and prospects for the future. Freshw. Biol. 2010, 55, 152-174. [CrossRef]

13. Catford, J.A.; Vesk, P.A.; Richardson, D.M.; Pysek, P. Quantifying levels of biological invasion: Towards the objective classification of invaded and invasible ecosystems. Glob. Chang. Biol. 2012, 18, 44-62. [CrossRef]

14. Simberloff, D.; Martin, J.-L.; Genovesi, P.; Maris, V.; Wardle, D.A.; Aronson, J.; Courchamp, F.; Galil, B.; García-Berthou, E.; Pascal, M. Impacts of biological invasions: What's what and the way forward. Trends Ecol. Evol. 2013, 28, 58-66. [CrossRef] [PubMed]

15. Seebens, H.; Bacher, S.; Blackburn, T.M.; Capinha, C.; Dawson, W.; Dullinger, S.; Genovesi, P.; Hulme, P.E.; van Kleunen, M.; Kühn, I. Projecting the continental accumulation of alien species through to 2050. Glob. Chang. Biol. 2020, 27, 970-982. [CrossRef] [PubMed]

16. Russell, J.C.; Sataruddin, N.S.; Heard, A.D. Over-invasion by functionally equivalent invasive species. Ecology 2014, 95, 2268-2276. [CrossRef]

17. Copp, G.H.; Fox, M.G. Can invasiveness in freshwater fishes be predicted from life-history traits? Front. Ecol. Evol. 2020, 8, 408 [CrossRef]

18. Fox, M.; Vila-Gispert, A.; Copp, G. Life-history traits of introduced Iberian pumpkinseed Lepomis gibbosus relative to native populations. Can differences explain colonization success? J. Fish Biol. 2007, 71, 56-69. [CrossRef]

19. Crandall, K.A.; De Grave, S. An updated classification of the freshwater crayfishes (Decapoda: Astacidea) of the world, with a complete species list. J. Crustacean Biol. 2017, 37, 615-653. [CrossRef]

20. Momot, W.T. Redefining the role of crayfish in aquatic ecosystems. Rev. Fish Sci. 1995, 3, 33-63. [CrossRef]

21. Lipták, B.; Veselý, L.; Ercoli, F.; Bláha, M.; Buřič, M.; Ruokonen, T.; Kouba, A. Trophic role of marbled crayfish in a lentic freshwater ecosystem. Aquat. Invasions 2019, 14, 299-309. [CrossRef]

22. Lodge, D.M.; Deines, A.; Gherardi, F.; Yeo, D.C.J.; Arcella, T.; Baldridge, A.K.; Barnes, M.A.; Chadderton, W.L.; Feder, J.L.; Gantz, C.A.; et al. Global Introductions of Crayfishes: Evaluating the Impact of Species Invasions on Ecosystem Services. Annu. Rev. Ecol. Evol. Syst. 2012, 43, 449-472. [CrossRef]

23. Gherardi, F.; Aquiloni, L.; Dieguez-Uribeondo, J.; Tricarico, E. Managing invasive crayfish: Is there a hope? Aquat. Sci. 2011, 73, 185-200. [CrossRef]

24. Holdich, D.M.; Reynolds, J.D.; Souty-Grosset, C.; Sibley, P.J. A review of the ever increasing threat to European crayfish from non-indigenous crayfish species. Knowl. Manag. Aquat. Ecosyst. 2009, 394-395, 11. [CrossRef]

25. Kouba, A.; Petrusek, A.; Kozák, P. Continental-wide distribution of crayfish species in Europe: Update and maps. Knowl. Manag. Aquat. Ecosyst. 2014, 413, 5. [CrossRef]

26. EU. Regulation (EU) No 1143/2014 of the European Parliament and of the Council of 22 October 2014 on the prevention and management of the introduction and spread of invasive alien species. Off. J. Eur. Union 2014, 57, 35.

27. EU. Commission Implementing Regulation (EU) 2016/1141 of 13 July 2016 adopting a list of invasive alien species of Union concern pursuant to Regulation (EU) No 1143/2014 of the European Parliament and of the Council. Off. J. Eur. Union 2016, 189, $4-8$.

28. Svoboda, J.; Mrugała, A.; Kozubíková-Balcarová, E.; Petrusek, A. Hosts and transmission of the crayfish plague pathogen Aphanomyces astaci: A review. J. Fish Dis. 2017, 40, 127-140. [CrossRef] [PubMed]

29. Vorburger, C.; Ribi, G. Aggression and competition for shelter between a native and an introduced crayfish in Europe. Freshw. Biol. 1999, 42, 111-119. [CrossRef]

30. Kouba, A.; Tíkal, J.; Císař, P.; Veselý, L.; Fořt, M.; Příborský, J.; Patoka, J.; Buřrič, M. The significance of droughts for hyporheic dwellers: Evidence from freshwater crayfish. Sci. Rep. 2016, 6, 26569. [CrossRef]

31. Kozák, P.; Buřič, M.; Policar, T.; Hamáčková, J.; Lepičová, A. The effect of inter-and intra-specific competition on survival and growth rate of native juvenile noble crayfish Astacus astacus and alien spiny-cheek crayfish Orconectes limosus. Hydrobiologia 2007, 590, 85-94. [CrossRef]

32. Souty-Grosset, C.; Holdich, D.M.; Noël, P.Y.; Reynolds, J.; Haffner, P. Atlas of Crayfish in Europe; Muséum National d'Histoire Naturelle: Paris, France, 2006. 
33. Lodge, D.M.; Taylor, C.A.; Holdich, D.M.; Skurdal, J. Nonindigenous crayfishes threaten North American freshwater biodiversity: Lessons from Europe. Fisheries 2000, 25, 7-20. [CrossRef]

34. Weiperth, A.; Bláha, M.; Szajbert, B.; Seprős, R.; Bányai, Z.; Patoka, J.; Kouba, A. Hungary: A European hotspot of non-native crayfish biodiversity. Knowl. Manag. Aquat. Ecosyst. 2020, 421, 43. [CrossRef]

35. Weiperth, A.; Gál, B.; Kuříková, P.; Bláha, M.; Kouba, A.; Patoka, J. Cambarellus patzcuarensis in Hungary: The first dwarf crayfish established outside of North America. Biologia 2017, 72, 1529-1532. [CrossRef]

36. Szendőfi, B.; Bérces, S.; Csányi, B.; Gábris, V.; Gál, B.; Gönye, Z.; Répás, E.; Seprős, R.; Tóth, B.; Kouba, A.; et al. Egzotikus halfajok és decapodák a Barát-és Dera-patakban, valamint a torkolatuk dunai élőhelyein (Occurrence of exotic fish and crayfish species in Barát and Dera creeks and their adjacent section of the River Danube). Pisces Hung. 2018, 12, 47-51.

37. Grandjean, F.; Collas, M.; Uriarte, M.; Rousset, M. First record of a marbled crayfish Procambarus virginalis (Lyko, 2017) population in France. Bioinvasions Rec. 2021, 10. in press. [CrossRef]

38. Jackson, M.C.; Jones, T.; Milligan, M.; Sheath, D.; Taylor, J.; Ellis, A.; England, J.; Grey, J. Niche differentiation among invasive crayfish and their impacts on ecosystem structure and functioning. Freshw. Biol. 2014, 59, 1123-1135. [CrossRef]

39. Veselý, L.; Buřič, M.; Kouba, A. Hardy exotics species in temperate zone: Can "warm water" crayfish invaders establish regardless of low temperatures? Sci. Rep. 2015, 5, 16340. [CrossRef] [PubMed]

40. Veselý, L.; Ruokonen, T.J.; Weiperth, A.; Kubec, J.; Szajbert, B.; Guo, W.; Ercoli, F.; Bláha, M.; Buřrič, M.; Hämäläinen, H. Trophic niches of three sympatric invasive crayfish of EU concern. Hydrobiologia 2021, 848, 727-737. [CrossRef]

41. Vogt, G. Biology, Eecology, Evolution, Systematics and Utilization of the Parthenogenetic Marbled crayfish, Procambarus virginalis. In Crayfish: Evolution, Habitat and Conservation Strategies; Ribeiro, F.B., Ed.; Nova Science Publishers: Hauppauge, NY, USA, 2020; pp. 137-227.

42. Kawai, T.; Kouba, A. A description of postembryonic development of Astacus astacus and Pontastacus leptodactylus. Freshw. Crayfish 2020, 25, 103-116. [CrossRef]

43. Kouba, A.; Hamáčková, J.; Buřič, M.; Policar, T.; Kozak, P. Use of three forms of decapsulated Artemia cysts as food for juvenile noble crayfish (Astacus astacus). Czech J. Anim. Sci. 2011, 56, 114-118. [CrossRef]

44. Veselý, L.; Hrbek, V.; Kozák, P.; Buřič, M.; Sousa, R.; Kouba, A. Salinity tolerance of marbled crayfish Procambarus fallax f. virginalis. Knowl. Manag. Aquat. Ecosyst. 2017, 418, 21. [CrossRef]

45. Therneau, T.M.; Grambsch, P.M. Therneau, T.M.; Grambsch, P.M. The Cox Model. In Modeling Survival Data: Extending the Cox Model; Springer: Berlin/Heidelberg, Germany, 2000; pp. 39-77.

46. Zuur, A.; Ieno, E.N.; Walker, N.; Saveliev, A.A.; Smith, G.M. Mixed Effects Models and Extensions in Ecology with R; Springer Science \& Business Media: Berlin/Heidelberg, Germany, 2009.

47. Cucherousset, J.; Copp, G.H.; Fox, M.G.; Sterud, E.; van Kleef, H.H.; Verreycken, H.; Záhorská, E. Life-history traits and potential invasiveness of introduced pumpkinseed Lepomis gibbosus populations in northwestern Europe. Biol. Invasions 2009, 11, 2171-2180. [CrossRef]

48. Grabowska, J.; Przybylski, M. Life-history traits of non-native freshwater fish invaders differentiate them from natives in the Central European bioregion. Rev. Fish Biol. Fish. 2015, 25, 165-178. [CrossRef]

49. Pintor, L.M.; Sih, A. Differences in growth and foraging behavior of native and introduced populations of an invasive crayfish. Biol. Invasions 2009, 11, 1895-1902. [CrossRef]

50. Chucholl, C.; Morawetz, K.; Gross, H. The clones are coming—strong increase in Marmorkrebs Procambarus fallax (Hagen, 1870) f. virginalis records from Europe. Aquat. Invasions 2012, 7, 511-519. [CrossRef]

51. Velisek, J.; Stara, A.; Zuskova, E.; Kouba, A. Effects of three triazine metabolites and their mixture at environmentally relevant concentrations on early life stages of marbled crayfish (Procambarus fallax f. virginalis). Chemosphere 2017, 175, 440-445. [CrossRef]

52. Holdich, D.M. Biology of Freshwater Crayfish; Blackwell Science Oxford: Oxford, UK, 2002.

53. Lipták, B.; Mojžišová, M.; Grul'a, D.; Christophoryová, J.; Jablonski, D.; Bláha, M.; Petrusek, A.; Kouba, A. Slovak section of the Danube has its well-established breeding ground of marbled crayfish Procambarus fallax f. virginalis. Knowl. Manag. Aquat. Ecosyst. 2017, 418, 40. [CrossRef]

54. Tönges, S.; Masagounder, K.; Gutekunst, J.; Lohbeck, J.; Miller, A.K.; Boehl, F.; Lyko, F. Physiological properties and tailored feeds to support aquaculture of marbled crayfish in closed systems. bioRxiv 2020. [CrossRef]

55. Andriantsoa, R.; Tönges, S.; Panteleit, J.; Theissinger, K.; Carneiro, V.C.; Rasamy, J.; Lyko, F. Ecological plasticity and commercial impact of invasive marbled crayfish populations in Madagascar. BMC Ecol. 2019, 19, 8. [CrossRef] [PubMed]

56. Jones, J.P.G.; Rasamy, J.R.; Harvey, A.; Toon, A.; Oidtmann, B.; Randrianarison, M.H.; Raminosoa, N.; Ravoahangimalala, O.R. The perfect invader: A parthenogenic crayfish poses a new threat to Madagascar's freshwater biodiversity. Biol. Invasions 2009, 11, 1475-1482. [CrossRef]

57. Maiakovska, O.; Andriantsoa, R.; Tönges, S.; Legrand, C.; Gutekunst, J.; Hanna, K.; Pârvulescu, L.; Novitsky, R.; Weiperth, A.; Sciberras, A.; et al. Genome analysis of the monoclonal marbled crayfish reveals genetic separation over a short evolutionary timescale. Commun. Biol. 2021, 4, 1-7. [CrossRef]

58. Hossain, M.S.; Kouba, A.; Buřič, M. Morphometry, size at maturity, and fecundity of marbled crayfish (Procambarus virginalis). Zool. Anz. 2019, 281, 68-75. [CrossRef]

59. Pieplow, U. Fischereiwissenschaftliche Monographie von Cambarus affinis Say. Z. Für Fish. 1938, 36, 349-440. 
60. Chybowski, Ł. Morphometrics, fecundity, density, and feeding intensity of the spinycheek crayfish, Orconectes limosus (Raf.) in natural conditions. Fish. Aquat. Life 2007, 15, 175-241.

61. Kozák, P.; Ďuriš, Z.; Petrusek, A.; Buřič, M.; Horká, I.; Kouba, A.; Kozubíková-Balcarová, E.; Policar, T. Crayfish Biology and Culture; University of South Bohemia in České Budějovice, Faculty of Fisheries and Protection of Waters: Vodňany, Czech Republic, 2015.

62. Guan, R.-Z.; Wiles, P.R. Growth and reproduction of the introduced crayfish Pacifastacus leniusculus in a British lowland river. Fish. Res. 1999, 42, 245-259. [CrossRef]

63. Buřič, M.; Haubrock, P.J.; Veselý, L.; Kozák, P.; Kouba, A. Effective investments due to seasonal morphological changes? Possible reasons and consequences of allometric growth and reproduction in adult signal crayfish (Pacifastacus leniusculus). Can. J. Zool. 2021, 99, 85-96. [CrossRef]

64. Westman, K.; Savolainen, R.; Pursiainen, M. A comparative study on the growth and moulting of the noble crayfish, Astacus astacus (L.), and the signal crayfish, Pacifastacus leniusculus (Dana), in a small forest lake in southern Finland. Freshw. Crayfish $1993,9,451-465$.

65. Abrahamsson, S.A. Density, growth and reproduction in populations of Astacus astacus and Pacifastacus leniusculus in an isolated pond. Oikos 1971, 22, 373-380. [CrossRef]

66. Ackefors, H.E. Freshwater crayfish farming technology in the 1990s: A European and global perspective. Fish Fish. 2000, 1, 337-359. [CrossRef]

67. Wickins, J.F.; Lee, D.O.C. Crustacean Farming: Ranching and Culture; John Wiley \& Sons: Hoboken, NJ, USA, 2008.

68. Oficialdegui, F.J.; Sánchez, M.I.; Clavero, M. One century away from home: How the red swamp crayfish took over the world. Rev. Fish Biol. Fish. 2020, 30, 121-135. [CrossRef]

69. Haubrock, P.J.; Oficialdegui, F.J.; Zeng, Y.; Patoka, J.; Yeo, D.C.; Kouba, A. The redclaw crayfish: A prominent aquaculture species with invasive potential in tropical and subtropical biodiversity hotspots. Rev. Aquac. 2021, accepted. [CrossRef]

70. Kouba, A.; Kanta, J.; Buřič, M.; Policar, T.; Kozák, P. The effect of water temperature on the number of moults and growth of juvenile noble crayfish, Astacus astacus (Linneaus). Freshw. Crayfish 2010, 17, 37-41.

71. Hartnoll, R.G. Growth in Crustacea-Twenty Years on. In Advances in Decapod Crustacean Research. Developments in Hydrobiology; Paula, J.P.M., Flores, A.A.V., Fransen, C.H.J.M., Eds.; Springer: Dordrecht, The Nezerlands, 2001; Volume 154, pp. 111-122.

72. Lindqvist, O.V.; Huner, J.V. Life history characteristics of crayfish: What makes some of them good colonizers? In Crayfish in Europe as Alien Species: How to Make the Best of a Bad Situation; Gheraardi, F., Holdich, D.M., Eds.; Crustacean Issues; Routledge: London, UK, 1999; Volume 11, pp. 23-30.

73. Hudina, S.; Hock, K.; Žganec, K. The role of aggression in range expansion and biological invasions. Curr. Zool. 2014, 60, 401-409. [CrossRef]

74. Pârvulescu, L.; Stoia, D.I.; Miok, K.; Ion, M.C.; Puha, A.E.; Sterie, M.; Vereș, M.; Marcu, I.; Muntean, D.M.; Aburel, O.M. Force and boldness: Cumulative assets of a successful crayfish invader. Front. Ecol. Evol. 2021, 9, 49. [CrossRef]

75. Fořt, M.; Hossain, S.; Kouba, A.; Buřič, M.; Kozák, P. Agonistic interactions and dominance establishment in three crayfish species non-native to Europe. Limnologica 2019, 74, 73-79. [CrossRef]

76. Jimenez, S.A.; Faulkes, Z. Can the parthenogenetic marbled crayfish Marmorkrebs compete with other crayfish species in fights? J. Ethol. 2011, 29, 115-120. [CrossRef]

77. Hossain, S.; Kubec, J.; Kouba, A.; Kozák, P.; Buřič, M. Still waters run deep: Marbled crayfish dominate over red swamp crayfish in agonistic interactions. Aquat. Ecol. 2019, 53, 97-107. [CrossRef]

78. Kouba, A.; Buřič, M.; Policar, T.; Kozák, P. Evaluation of body appendage injuries to juvenile signal crayfish (Pacifastacus leniusculus): Relationships and consequences. Knowl. Manag. Aquat. Ecosyst. 2011, 401, 4. [CrossRef]

79. Buřič, M.; Kouba, A.; Kozák, P. Chelae regeneration in European alien crayfish Orconectes limosus (Rafinesque 1817). Knowl. Manag. Aquat. Ecosyst. 2009, 394-395, 4. [CrossRef]

80. Niksirat, H.; Kouba, A.; Kozák, P. Ultrastructure of egg activation and cortical reaction in the noble crayfish Astacus astacus. Micron 2015, 68, 115-121. [CrossRef] [PubMed]

81. Guo, W.; Kubec, J.; Veselý, L.; Hossain, M.S.; Buřič, M.; McClain, R.; Kouba, A. High air humidity is sufficient for successful egg incubation and early post-embryonic development in the marbled crayfish (Procambarus virginalis). Freshw. Biol. 2019, 64, 1603-1612. [CrossRef]

82. Seitz, R.; Vilpoux, K.; Hopp, U.; Harzsch, S.; Maier, G. Ontogeny of the Marmorkrebs (marbled crayfish): A parthenogenetic crayfish with unknown origin and phylogenetic position. J. Exp. Zool. Part A Comp. Exp. Biol. 2005, 303A, 393-405. [CrossRef]

83. Vogt, G. Suitability of the clonal marbled crayfish for biogerontological research: A review and perspective, with remarks on some further crustaceans. Biogerontology 2010, 11, 643-669. [CrossRef] [PubMed]

84. Chucholl, C.; Pfeiffer, M. First evidence for an established Marmorkrebs (Decapoda, Astacida, Cambaridae) population in Southwestern Germany, in syntopic occurrence with Orconectes limosus (Rafinesque, 1817). Aquat. Invasions 2010, 5, 405-412. [CrossRef]

85. Huner, J. Procambarus; Blackwell Science: Oxford, UK, 2002; pp. 541-584.

86. Avault, J.W., Jr. Crawfish farming in the United States. Freshw. Crayfish 1972, 1, 239-250.

87. Oluoch, A. Breeding biology of the Louisiana red swamp crayfish Procambarus clarkii Girard in Lake Naivasha, Kenya. Hydrobiologia 1990, 208, 85-92. [CrossRef]

88. Buřič, M.; Kouba, A.; Kozák, P. Intra-sex dimorphism in crayfish females. Zoology 2010, 113, 301-307. [CrossRef] 
89. Buřič, M.; Kouba, A.; Kozák, P. Molting and growth in relation to form alternations in the male spiny-cheek crayfish Orconectes limosus. Zool. Stud. 2010, 49, 28-38.

90. Stucki, T.P. Diffrences in life history of native and introduced crayfish species in Switzerland. Freshw. Crayfish 2002, 13, 463-476.

91. Kozák, P.; Buřič, M.; Policar, T. The fecundity, time of egg development and juvenile production in spiny-cheek crayfish (Orconectes limosus) under controlled conditions. Bull. Français Pêche Piscic. 2006, 380-381, 1171-1182. [CrossRef]

92. Lipták, B.; Mrugała, A.; Pekárik, L.; Mutkovič, A.; Grul'a, D.; Petrusek, A.; Kouba, A. Expansion of the marbled crayfish in Slovakia: Beginning of an invasion in the Danube catchment? J. Limnol. 2016, 75, 305-312. [CrossRef]

93. Kirjavainen, J.; Westman, K. Development of an introduced signal crayfish (Pacifastacus leniusculus (Dana)) population in the small Lake Karisjärvi in central Finland. Freshw. Crayfish 1995, 10, 140-150.

94. Kirjavainen, J.; Westman, K. Natural history and development of the introduced signal crayfish, Pacifastacus leniusculus, in a small, isolated Finnish lake, from 1968 to 1993. Aquat. Living Resour. 1999, 12, 387-401. [CrossRef]

95. Savolainen, R.; Westman, K.; Pursiainen, M. Fecundity of Finnish noble crayfish, Astacus astacus L., and signal crayfish, Pacifastacus leniusculus, in various natural habitats and in culture. Freshw. Crayfish 1996, 11, 319-338.

96. Beatty, S.; Morgan, D.; Gill, H. Role of life history strategy in the colonisation of Western Australian aquatic systems by the introduced crayfish Cherax destructor Clark, 1936. Hydrobiologia 2005, 549, 219-237. [CrossRef]

97. Johnston, K.; Robson, B.J.; Austin, C.M. Population structure and life history characteristics of Euastacus bispinosus and Cherax destructor (Parastacidae) in the Grampians National Park, Australia. Freshw. Crayfish 2008, 16, 165-173.

98. Semple, G.; Rouse, D.; McLain, K. Cherax destructor, C. tenuimanus and C. quadricarinatus (Decapoda: Parastacidae): A comparative review of biological traits relating to aquaculture potential. Freshw. Crayfish 1995, 8, 495-503.

99. Austin, C. A comparison of clutch and brood size in the Red Claw, Cherax quadricarinatus (von Martens) and the Yabby, C. destructor Clark (Decapoda: Parastacidae). Aquaculture 1998, 167, 135-145. [CrossRef]

100. Huner, J.V.; Barr, J.; Coleman, E.B. Red Swamp Crawfish: Biology and Exploitation; Louisiana Sea Grant College Program, Center for Wetland Resources, Louisiana State University: Barton Rouge, LA, USA, 1984.

101. Gutiérrez-Yurrita, P.J.; Del Olmo, C.M. Population dynamics of juveniles of red swamp crayfish (Procambarus clarkii) under controlled conditions. Freshw. Crayfish 2004, 14, 180-189. 